\title{
Socio-economic Condition of the Marginal Farmers: A Case Study on Madhupur Sal Forest Area
}

\author{
Noushin Farjana Huda Chowdhury \\ Mawlana Bhashani Science and Technology University \\ Santosh, Tangail-1902, Bangladesh \\ Email: noushin@mbstu.ac.bd \\ Monibur Rahman \\ Mawlana Bhashani Science and Technology University \\ Santosh, Tangail-1902, Bangladesh \\ Email: md.monibur.bd7@gmail.com \\ Kazi Mezbah Uddin Ahamad \\ Mawlana Bhashani Science and Technology University \\ Santosh, Tangail-1902, Bangladesh \\ Email: kazimezbah@mbstu.ac.bd
}

\begin{abstract}
:
As an agrarian economy, more than half of the population in Bangladesh belongs to small and marginal farm holding families. We cannot ignore their contribution to the national food supply and agricultural GDP. But in reality, they receive inadequate attention from the agricultural extension services compared to the well-off farmers. To investigate the socio-economic condition of the farmers, 200 farmers from Sholakury village under Madhupur Thana in Tangail District - where $56 \%$ of the farmers are landless and marginal, and $42 \%$ of the farmers are small - are chosen randomly as the source of data for the current study. This study aims to seek answers to the following question, "Why can the marginal farmers not be able to improve their economic status and why can they not increase the productivity of their cultivable land?" In searching for the answers the study discovers that a majority (83\%) of the farmers in this area do not have any training on cultivation. About $75 \%$ of farmers use hybrid seeds but $82 \%$ of them have never received any training on it. Also, noticeably, $56 \%$ of farmers do not have any savings and about $86 \%$ of the farmers are unable to use smart-phones and internet. We are ague that among others these are the major factors that worsen the economic status and decrease their productivity.
\end{abstract}

Keywords: Agriculture, Cultivation, Pesticides, Marginal farmers, Land-distribution

DOI: $10.7176 / \mathrm{DCS} / 11-5-05$

Publication date:May $31^{\text {st }} 2021$

\section{Introduction:}

In Bangladesh a large portion of household income is directly related to agricultural production. But income earned from agricultural activities is extremely volatile. Extant literature states that the economy of Bangladesh largely depends on farmers, readymade garments workers, and migrant laborers. Among them, the farmers are in 
the worst condition. Bumper productions of agricultural goods have been a common scene in Bangladesh for many decades since the independence. Despite this the farmers have always been struggling to meet the production costs. This raises the question, "Are the farmers properly getting paid at all?" Farmers in Bangladesh still face many challenges like loss of arable land, poor management of fertilizers, water, pest control, crop and livestock diseases, training on cultivation using modern techniques etc. The country's farm sector is dominated by smallholders but the small and marginal farmers get the least access to the credit and agricultural extension services provided by the state (The Daily Star, 2017).

Tangail is one of the country's biggest zones for mustard cultivation, producing about 50,000 tonnes a year (The Daily Star, 2021). More than one lac of farmers of crops and vegetables in Tangail incurred a loss of BDT 141 crores due to prolonged and devastating floods. As many as 11 out of the 12 upazilas in the district were affected by the floods due to onrush water from the upstream and heavy rains in August, September, and October ( Dhaka Tribune,2021). The primary objective of this study is to analyze the present socio-economic condition of marginal farmers at Madhupur sal forest area in Tangail District.

\section{Literature Review}

Lal et al. (2019) find that many small and marginal farmers committed suicide due to monsoon failure, high debt burdens, government policies, mental health, personal issues, and family problems at Telangana state in India. The study also shows that the majority of farmers shifted from food grain crops to commercial crops. Nearly 60 percent of farmers still depend on bull plow in case of cotton cultivation. In the case of rice, 95 percent of farmers depend on machines. According to Macharla et al (2017), many technological and institutional innovations may enable marginal and small farmers to raise their productivity in Karimnagar districts. Findings indicate that through crop diversification and high-value agriculture, farmers can raise their income easily.

Toufique (2017) finds that between 1973 and 2011, the net cropped area in Bangladesh has reduced annually by 0.2 percent per annum, while the gross cropped area has increased by 0.6 per annum. He says that to feed a growing population, Bangladesh needs to produce more. For employment generation, food security, and poverty alleviation, the importance of the agricultural sector has increased day by day.

Nasrin et al (2016) show that output prices play a noteworthy role, in addition to fertilizer prices, in enhancing fertilizer usage. Marginal and small farms' fertilizer usage depends mostly on their financial conditions, access to various credit institutions for getting help in case of crisis, and services received from extension agents. She suggests for Government intervention to enhance the purchasing capability of farmers and to reduce the distortions of resource allocation in framing the subsidy policy in the country.

Kabir et al. (2015) recommend some policy actions such as ensuring a minimum cropped area among farmers, accelerating the rate of genetic gain in varietal development, and increasing collaboration among the stakeholders to reduce time lag for adopting newly released promising rice varieties so that Bangladesh can achieve rice vision by 2050 .

Dev (2014) observes that new technological innovations are needed in reducing cost without reduction in yields. So, priority should be given to small holder-oriented research and extension. Mohajan (2013) finds that irrigation is a major challenge for farmers growing crops in the dry season in Bangladesh.

Kumar et al. (2013) show that climate change has a serious impact on agricultural productivity. Fluctuations in temperatures and irregular rainfall cause adverse effects on food grain productivity. The majority of the farmers purchase water from pump owners. In Bangladesh efficiency of water use for irrigation is low.

Uddin (2012) reveals that maximum marginal farmers were food insecure (56.67\%), while 30\% were moderately food secured and only $13 \%$ were food secured. Though adequate food was available in local markets those were beyond affordability.

Chand et al. (2011) suggest that the strategy of improving the crop land-man ratio by facilitating migration from rural India has not worked and will not work. The lives of smallholding families can be improved only by building on their higher per acre agricultural productivity and by promoting off-farm rural employment.

Munasinghe (2010) suggests that adaptation is indispensable against climate change to confirm sustainable development and to reduce the vulnerabilities of rural poor farmers. Lipton (2006) argues that initial success in the reduction of mass poverty requires prior agricultural developments. His arguments supporting the importance 
of agricultural development for poverty alleviation and explore in particular the role of small-scale farming and policy requirements to ensure the competitive advantage of small farms.

Rahman et al. (1996) find that by applying modern input and techniques, efficiency and productivity can easily be increased in rice farming. When productivity increases, medium farmers' highest yield rises to $6818 \mathrm{~kg} / \mathrm{ha}$ whereas small, marginal, and landless farmers' yield rises to $6359 \mathrm{~kg} / \mathrm{ha}, 6258 \mathrm{~kg} / \mathrm{ha}$, and $6127 \mathrm{~kg} / \mathrm{ha}$, respectively. Net return from rice farming is minimal. Medium farmers have the highest net earnings of 27033 Tk./ha whereas small, marginal, landless farmers' net earnings are $20716 \mathrm{Tk}$. /ha, 15601, 1278 Tk./ha respectively.

\section{Data Collection and Result Analysis}

The study was based on primary data. The data were collected through personal interview method coupled with a structured questionnaire (Cheung, 2014). The study was conducted at the Sholakury village in Tangail District. A simple random sampling method was used to collect data from a sample size of 200 out of 400 farmers. The village is located by the side of the Madhupur Sal forest area. Slovin's formula was used to determine the sample size from the known population. In the village, there were approximately 400 marginal farmer families. Here, the level of precision or sampling error (e) was fixed at 5\%, and the number of population (families) $\mathrm{N}=400$ and therefore, sample size (families) was found to be, $n=200$. The formula is stated below.

$$
n=\frac{N}{1+N(e)^{2}}
$$

\section{Present Socio-Economic Condition of Marginal Farmers}

Before going into the in-depth discussion it is worth mentioning the size of the land each farm category may hold. Here, farms according to their respective land sizes are defined as landless, marginal, small, medium and large of each farmer. Table 1 contains the land holding in acres of each farm category.

Table 1: Farm Size and Land Holding

\begin{tabular}{lc}
\hline Farm Category & Land Holdings (in Acres) \\
\hline Landless & Less than 0.05 \\
Marginal & $0.05-0.49$ \\
Small & $0.50-2.47$ \\
Medium & $2.48-7.41$ \\
Large & More than 7.41 \\
\hline
\end{tabular}

Source: BBS(2013)

Due to a large variation in the sizes of farmland owned by the farmers, data were collected for several categories to understand the nature of variation in this study area. It also enabled us to capture the existing diverse nature of the socio-economic condition of the farmers according to the size of their farmland. Here we assumed that a large farmland would benefit a farmer and his family in terms of education, savings, reinvestment and superior social status.

As per the information obtained, it was apparent that about $56 \%$ of the farmers belonged to the categories of landless and marginal farmers. About $42 \%$ of farmers were small farmers. And, medium and large farmers accounted for only $2 \%$ of the total farmers in this region. Also, noticeably, a large share of farmers $(36.50 \%)$ owned land between 0.1 acres to 0.49 acres. Apparently, the region had more of landless and medium farmers than it had small farmers. And, the presence of medium as well as large farmers was also negligible in this region. Figure 1 depicts the overall land distribution scenario among the farmers at the Madhupur sal forest area more intuitively. 
Table 2: Land Distribution Among the Farmers

\begin{tabular}{lc}
\hline Amount of land (Acres) & Number of Farmers (\%) \\
\hline Below 0.1 & 19.50 \\
$0.1-0.49$ & 36.50 \\
$0.50-0.90$ & 17 \\
$1-1.49$ & 14 \\
$1.50-1.99$ & 7 \\
$2-2.5$ & 4 \\
Above 2.5 & 2 \\
\hline
\end{tabular}

Data source: Author

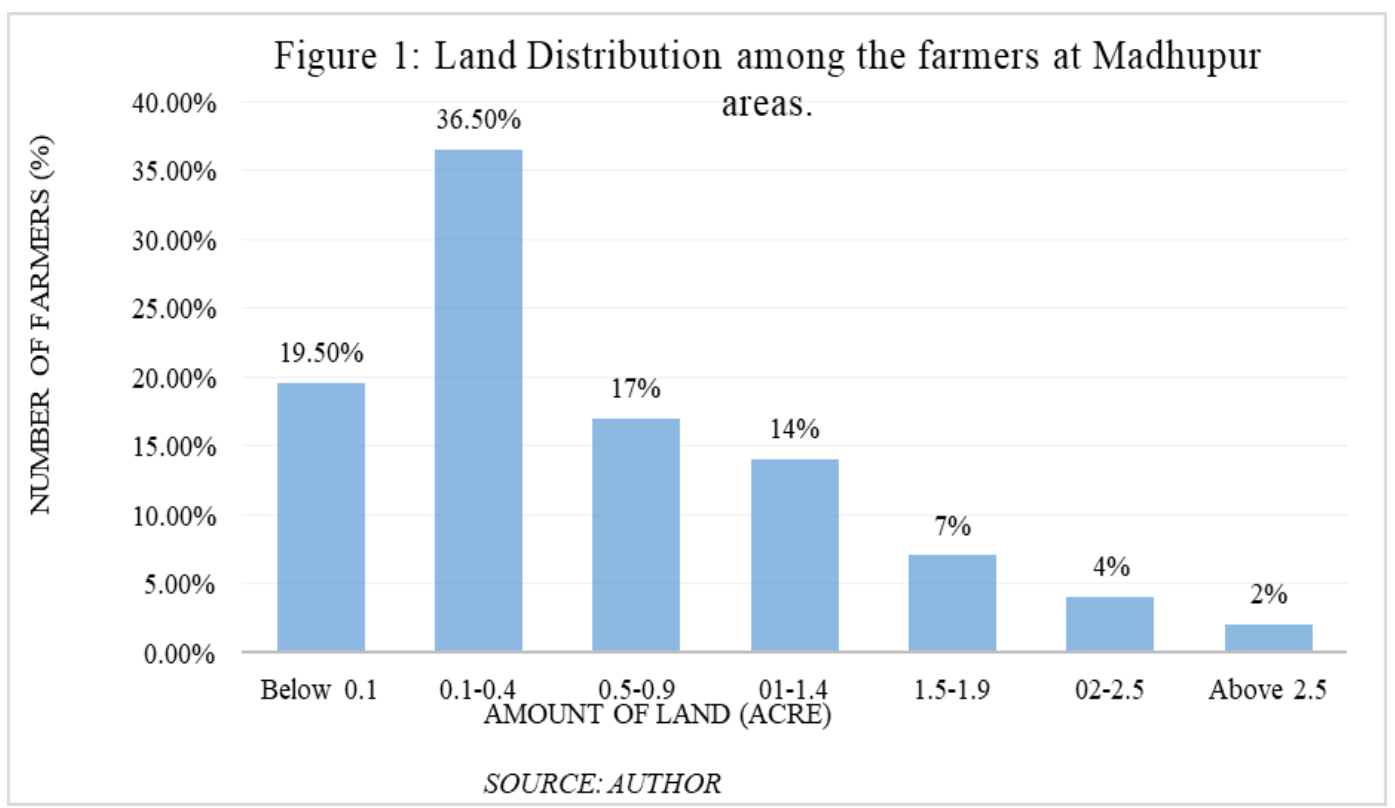

Figure 2 provides the overall scenario of the land ownership pattern among the farmers in the study area. About $64 \%$ of the farmers did not possess own land for cultivation. They had to cultivate land by taking lease from the landlords. Only $36 \%$ of farmers cultivated own land. As more than half of the total farmers possessed no land of their own, majority of their earnings went to the landlords' pocket. Also due to this fact, they did not have enough cash to save and reinvest. 


\section{FIGURE 2 PATTERN OF LAND OWNERSHIP AMONG THE FARMERS}

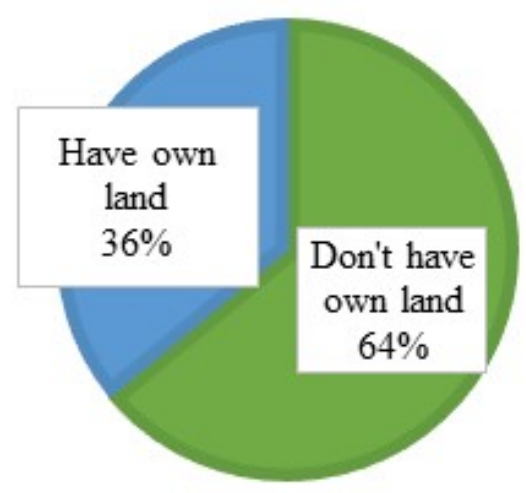

Source: Author

As the small and marginal farmers could not generate enough savings and they could not get proper or no access at all to credit, many of them had been compelled to sell their lands in the face of financial crisis.

Figure 3: Percentage of Farmers Buying and Selling Land in Last 5 Years

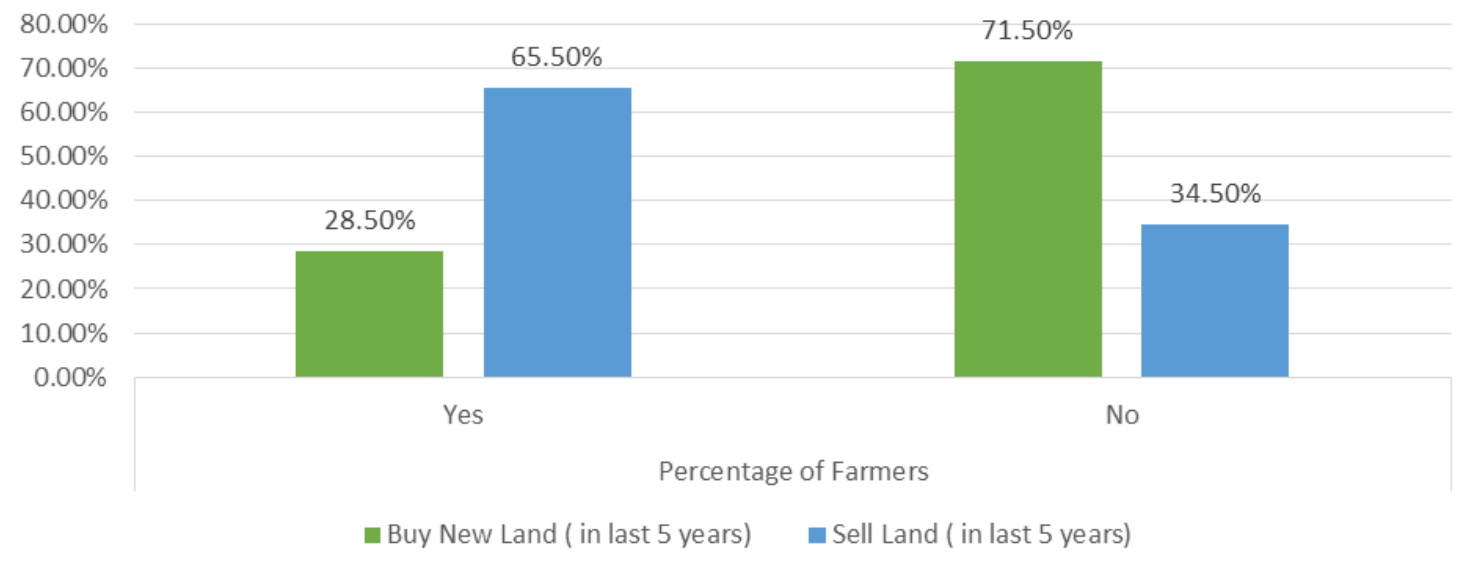

Source: Author

Figure 3 shows that in the last five years the trend of selling lands had been greater than that of purchasing new lands by the farmers in this particular region. It was observed that about $28.50 \%$ of farmers had purchased new land. On the other hand, about $65.50 \%$ of farmers had sold their land in the last 5 years.

Table 3 shows the size of land purchased and sold by the farmers in the study area in the last 5 years. Overall, the tendency of selling lands was larger than buying lands among the farmers in this area. If the land size was below 0.1 acres, only then farmers would be able to purchase some lands. In the last 5 years, $76.5 \%$ of farmers bought less than 0.1 acres of land and only $12.50 \%$ of farmers bought more than 0.1 acres. The percentage of buying land above 2 acres was very low $(0.5 \%)$ among the farmers. 


\begin{tabular}{lcc}
\hline \multicolumn{3}{c}{ Table 3: Size of land bought and sold in the last 5 years } \\
\hline \multicolumn{1}{c}{ Size of Land (Acres) } & $\begin{array}{c}\text { Percentage of Farmers Buying } \\
\text { Land (in last 5 years) }\end{array}$ & $\begin{array}{c}\text { Percentage of Farmers } \\
\text { Selling Land (in last 5 years) }\end{array}$ \\
\hline Below 0.1 & 76.5 & 41.5 \\
$0.1-0.49$ & 12.5 & 18 \\
$0.50-0.99$ & 5.5 & 17.5 \\
$1-1.49$ & 3.5 & 13 \\
$1.5-2$ & 1.5 & 7.5 \\
Above 2 & 0.5 & 2.5 \\
\hline
\end{tabular}

Data source: Author

\section{Figure 5: Housing Status of the Farmers.}

$$
\begin{aligned}
& \text { " Hut } \\
& \text { - Tin shed house } \\
& \text { = Tin shed building } \\
& \text { - Full building }
\end{aligned}
$$

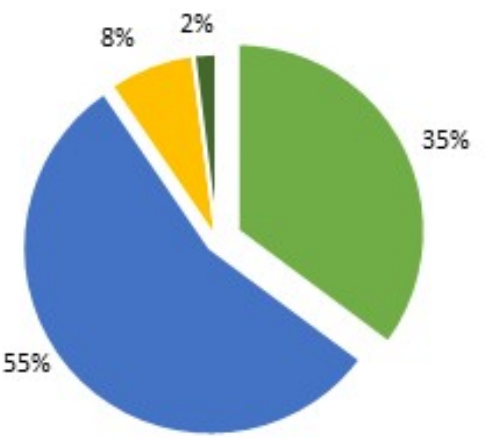

Source: Author

On the other hand, trend of selling land was higher among the farmers in this area between 0.1 to above 2 acres of land. In the last 5 years $41.50 \%$ of farmers sold less than 0.1 acres of land, and when it came to 0.1 to above 2 acres about $58.5 \%$ of the farmers sold more than they bought land for cultivation. Also, noticeably, in the last five years only $0.5 \%$ of farmers bought new land above 2 acres. The pie chart (Figure 4) represents the housing status of the marginal farmers. The majority (55\%) of the farmers live in temporary tin-shed houses (locally known as kutcha house). About $35 \%$ and $8 \%$ of the marginal farmers live in huts (shacks) and tin-shed buildings (locally known as semi-pucca house) respectively. Only $2 \%$ of the farmers live in permanent full-building houses (locally known as pucca house).

\section{Training about Pesticides, Hybrid Seeds and Cultivation}

Farmers with proper knowledge and training can produce more crops than those of non-trained farmers cultivating the same amount of land. Gautam et al (2017) find that in Bangladesh, trained farmers have better knowledge about insects, pests and the proper use of pesticides. They also find that these farmers adopt more integrated pest management (IPM) practices, and reduce the frequency of spraying and mixing different pesticides.

Table 3 shows the present status of landless and marginal farmers regarding the use and training on hybrid seeds and pesticides in the study area. Here the first column of table 3 includes the categories "Training on Cultivation", "Use of Hybrid Seeds", "Training on Use of Hybrid Seeds", "Use of Pesticides" and "Training on Use of Pesticides" respectively. The next two columns represent the percentage of farmers who belong to each category. 


\begin{tabular}{lcc}
\hline \multicolumn{3}{c}{ Table 3: Present Status About The Use And Training of Hybrid Seeds and Pesticides } \\
\hline & \multicolumn{2}{c}{ Percentage of Farmers } \\
\hline & Yes & No \\
Training on Cultivation & 17 & 83 \\
Use of Hybrid Seeds & 75 & 25 \\
Training on Use of Hybrid Seeds & 18 & 82 \\
Use of Pesticides & 78.5 & 21.5 \\
Training on Use of Pesticides & 13 & 87 \\
& & \\
\hline Data source: Author & & \\
\hline
\end{tabular}

According to the Table 3, the majority (about 83\%) of the farmers in this rural area did not have any training on cultivation. About $75 \%$ of farmers used hybrid seeds but $82 \%$ of farmers didn't have any training on the use of hybrid seeds. A similar situation was noticeable in the case of using pesticides. Around $78.50 \%$ of farmers used pesticides but only $13 \%$ of them took training on the use of pesticides.

\section{Education Level and Financial Status of Landless and Marginal Farmers}

Education plays an important role in development. Educated farmers know better about the use of technology and pesticides, and produce crops efficiently and sell these at maximum price.

Table 4: Education Level of The Landless And Marginal Farmers

\begin{tabular}{lc}
\hline Education Level & Number of Farmers (\%) \\
\hline Illiterate & 53.5 \\
Primary & 36 \\
Secondary & 7 \\
Higher Secondary & 3.5 \\
\hline Source: Author & \\
\hline
\end{tabular}

Table 4 represents the education level of the marginal farmers in the study area. The first column denotes the category of education level. The next column represents the percentage of farmers belonging to each category. According to the table 4, a majority $(53.5 \%)$ of the farmers were illiterate. Farmers with secondary and higher secondary education level were only $7 \%$ and $3.5 \%$ respectively. The percentage of farmers with primary education was approximately $36 \%$.

\section{Participation of Family Members in Cultivation:}

Table 5 depicts the involvement of the other family members of the farmers in the study area in agriculture. It shows that the majority of the families $(26.40 \%)$ consisted of four members. About $44.50 \%$ of total families had two children. According to this table, the number of children above three was rare among these families. Most of the families had to depend on a single earning person. About $60.50 \%$ of families had only one earning person. It was also clear that a large number of families $(64 \%)$ had only one person working in the agricultural sector. Only $8 \%$ of families had three people working in agricultural sector. 
Table 5: Family Status of the Landless and Marginal Farmers

\begin{tabular}{|c|c|c|c|c|c|c|c|}
\hline \multicolumn{2}{|c|}{ Family member } & \multicolumn{2}{|c|}{ Number of children } & \multicolumn{2}{|c|}{$\begin{array}{l}\text { Earning member of the } \\
\text { family }\end{array}$} & \multicolumn{2}{|c|}{$\begin{array}{l}\text { The member involved in } \\
\text { agriculture. }\end{array}$} \\
\hline $\begin{array}{l}\text { Number } \\
\text { of } \\
\text { members }\end{array}$ & $\begin{array}{l}\text { Number } \\
\text { of families }\end{array}$ & $\begin{array}{l}\text { Number } \\
\text { of child }\end{array}$ & $\begin{array}{l}\text { Number } \\
\text { of families }\end{array}$ & $\begin{array}{c}\text { Number of } \\
\text { members }\end{array}$ & $\begin{array}{l}\text { Number } \\
\text { of families }\end{array}$ & $\begin{array}{c}\text { Number } \\
\text { of } \\
\text { members }\end{array}$ & $\begin{array}{l}\text { Number } \\
\text { of families }\end{array}$ \\
\hline 2 & $1.50 \%$ & 0 & $3 \%$ & 1 & $60.50 \%$ & 1 & $64 \%$ \\
\hline 3 & $20 \%$ & 1 & $29.50 \%$ & 2 & $27.50 \%$ & 2 & $28 \%$ \\
\hline 4 & $26.50 \%$ & 2 & $44.5 \%$ & 3 & $8 \%$ & 3 & $8 \%$ \\
\hline 5 & $23.50 \%$ & 3 & $11 \%$ & 4 & $4 \%$ & & \\
\hline 6 & $15.50 \%$ & 4 & $9.50 \%$ & & & & \\
\hline 7 & $7 \%$ & 5 & $2 \%$ & & & & \\
\hline 8 & $2.50 \%$ & 6 & $0.50 \%$ & & & & \\
\hline 9 & $1 \%$ & & & & & & \\
\hline 10 & $2.50 \%$ & & & & & & \\
\hline
\end{tabular}

Source: Author

\section{Financial and Technological Status of the Landless and Marginal Farmers}

Marginal farmers of the Madhupur Sal forest area currently do not get enough social or financial assistance. Our data also depicted the same fact. As per Table 6 about $56.50 \%$ of farmers did not have any savings, $78.50 \%$ of farmers borrowed loans from various private sources, including NGOs, relatives, private banks, and moneylenders for cultivation purposes with a high-interest rate. The farmers had limited access to modern technology. Only $13.50 \%$ of farmers used smart phones and $13 \%$ of them used the internet in this region.

Table 6: Financial And Technological Status of The Landless and Marginal Farmers
\begin{tabular}{lccccccc}
\multicolumn{7}{l}{} \\
\hline \multicolumn{2}{l}{ Savings percentage } & Loan percentage & Use of smart phone (\%) & Use of the internet (\%) \\
\hline Yes & No & Yes & No & Yes & No & Yes & No \\
\hline 43.5 & 56.5 & 78.5 & 21.5 & 13.5 & 86.5 & 13 & 86 \\
\hline
\end{tabular}

Source: Author

\section{Conclusion}

Based on the study, it is apparent that landless, marginal and small farmers account for a large fraction of the total farmers at Madhupur Sal forest area. That is, farmers here are predominantly poor. Also the study reveals that the majority of the farmers cultivate crops traditionally. They use pesticides but fail to realize the consequences of using those unscrupulously. These are mainly responsible for low productivity of agriculture in this region. Rapid shrinkage of their land and lack of effective long-term training programs are largely accountable for the misery of the farmers in this area. They are still far behind from using modern technology in agriculture. Farmers' education level, social status, credit and training facilities are some of the important factors that have an impact on a farmers' adoption of modern agricultural technologies. This study shows that the literacy level among farmers in this area is very low. A large portion of them doesn't even know the usage of smart phone let alone the use of other advanced technologies. As a profession, agriculture has been passed down to family members for generations but the traditional means of farming couldn't otherwise be abandoned which is another reason for the pervasive poor economic condition in this community. It should be realized that a positive change may come to the rural economy once the farmers get the benefit of their products properly. 


\section{References:}

Ahmad, R (2017). "Marginal farmers have the least access". Agricultural Credit, Extension Services. The Daily Star, FrontPage, Accessed May 1,2021

B. Suresh Lal \& Ilaiah Macharla (2019). Agrarian Distress and Farmers' Suicides in Telangana State: An Empirical Study, The Indian Economic Journal, https://www.researchgate.net/publication/338447859_Agrarian_Distress_and Farmers' Suicides in Te langana_State_An_Empirical_Study Accessed: March 30, 2021

BBS (2013) Statistical Pocket Book of Bangladesh. Bangladesh Bureau of Statistics, Ministry of Planning, Dhaka.

Chand, R., Prasanna, P. L., \& Singh, A. (2011). Farm size and productivity: Understanding the strengths of smallholders and improving their livelihoods. Economic and Political Weekly, 5-11.

Cheung A.K.L. (2014) Structured Questionnaires. In: Michalos A.C. (eds) Encyclopedia of Quality of Life and Well-Being Research. Springer, Dordrecht. https://doi.org/10.1007/978-94-007-0753-5_2888

Gautam.S, Schreinemachers.P, UddinM.U, \& Srinivasan.R (2017). Impact of training vegetable farmers in Bangladesh in integrated pest management (IPM), Crop Protection, Volume 102, Pages 161-169

Hazell, P. B. R., \& Rahman, A. (2014). New Directions for Smallholder agriculture (Illustrated ed.). Oxford University Press. https://doi.org/10.1093/acprof:oso/9780199689347.001.0001

Hossain, M., \& SMF, B. A. I. (2017). A Diagnostic Study on Bangladesh Agriculture. RED Working Paper Series, BRAC

Ilaiah Macharla et al (2017).Issues and Problems of Small and Marginal Farmer: A Study in Karimnagar District, International Journal of Academic Research, Vol.4, Issue-1 (2).

Kabir, M. S., Salam, M. U., Chowdhury, A., Rahman, N. M. F., Iftekharuddaula, K. M., Rahman, M. S., et al. (2015). Rice vision for Bangladesh: 2050 and beyond. Bangladesh Rice Journal,19(2), 1-18.

Key, N., Prager, D., \& Burns, C. (2017). Farm household income volatility: An analysis using panel data from a National Survey, ERR-226. U.S. Department of Agriculture, Economic Research Service.

Kumar, A, and Sharma, P (2013).Impact of Climate Variation on Agricultural Productivity and Food Security in Rural India. Economics Discussion Papers, No 2013-43, Kiel Institute for the World Economy. http://www.economics-ejournal.org/economics/discussionpapers/2013-43.

Lipton, M. (2006). Can small farmers survive, prosper, or be the key channel to cut mass poverty? eJADE: electronic Journal of Agricultural and Development Economics, 3(853-2016-56133), 58-85.

Mahendra Dev, S. (2014). Small farmers in India: Challenges and opportunities. Indira Gandhi Institute of Development Research, Mumbai. http://hdl.handle.net/2275/262

Mohajan, H. (2013) "Food, Agriculture and Economic Situation of Bangladesh," MPRA Paper 54240, University Library of Munich, Germany.

Munasinghe, M (2010). Addressing the Sustainable Development and Climate Change Challenges Together: Applying the Sustainomics Framework. Procedia Social and Behavioral Sciences, 41 (2010) 66346640 .

Nasrin, M. et al (2016). Factors affecting fertilizer use intensity among farm size groups: Perception about fertilizer subsidy policy in Bangladesh, Conference on International Research on Food Security, Natural Resource Management and Rural Development, Tropentag 2016, Vienna, Austria. September 18-21, 2016.

Numan, A. (2021). Tangail farmers busy cultivating honey to recoup flood loss. Dhaka Tribune. January 24th, 2021 
Rahman, M. M., Flitner, M., Krause, G., \& Maniruzzaman, M. (2008). Socioeconomic assessment of shrimp farming in relation to local livelihoods in the south-west coastal Bangladesh. Bangladesh Journal of Fisheries Research, 12(1), 109-120.

Shakil, M.(2021) “Tangail farmers enjoy bumper mustard yield, better prices". The Daily Star, February 28 , 2021.

Toufique, K. A. (2017). Bangladesh Experience in Rural Development: The Success and Failure of the Various Models Used. Bangladesh Development Studies, 40(1-2), 97-118.

Uddin, M. E. (2012). Household food security status of marginal farmers in selected storm surge prone coastal area of Bangladesh. The Agriculturists, 10(1), 98-103. 